\title{
Mismatched Perception and Expectation of Retail Stakeholders: An Assessment of Indian Retail Store Jobs
}

\section{Dr. Anju Verma ${ }^{1}$ Dr. Ubba Savita ${ }^{2}$}

Effulgence

Vol. 15 No. 2

July-December, 2017

Rukmini Devi Institute of Advanced Studies

E-mail : effulgence@rdias.ac.in, Website : www.rdias.ac.in http://effulgence.rdias.ac.in/user/default.aspx https://dx.doi.org/10.33601/effulgence.rdias/v15/i2/2017/33-43

\begin{abstract}
The organized Indian retail sector is rising exponentially with large number of job openings coming up in the retail sector, it becomes indispensable to identify the gaps in skills and job profile for the organized retail stores coming up in various parts of India. The present study is an attempt to have an insight of the skills and job profile in retail stores across India. The sample included the stakeholders of retail sector; the students (prospective employees) and the present retail employees in order to identify their mismatched understanding for the kind of skills required and the actual profile of a retail job. The findings highlight that technical, liasioning, creativity, interactive, leadership skills and prior degree/course make up the skills required for retail store job. The retail store job profile includes flexible working arrangements, responsiveness, sales analysis, contributing towards society and company; and other issues.
\end{abstract}

Keywords: Job profile, Job skills, Retail, Store.

\section{INTRODUCTION}

$\mathrm{I}$ ndia is regarded as one of the top and attractive retail destination in the world. With huge customer base having large disposable incomes, the world retailers are eyeing towards India. As the government has opened up the FDI in multi brand retailing in India, the opportunities in retail sector are rising from all directions. This will also give birth to large number of job openings in the front and back end operations in retail sector.
The history of retailing in India goes way back to early centuries when India was treated as the epitome of the business activities and retail activities were also immense. But looking at the revolutionized retail actions taking place around the world now, India is far behind with the traditional retail mode still dominating. However the figures are not so looming. The organized retail share in India is around 4 per cent but growing at whooping 24 per cent annually whereas the unorganized sector at a slower rate of 10-12 per cent (The Economic Times, 13-08-2012).

1. Assistant Professors, Haryana School of Business, Guru Jambheshwar University of Science \& Technology, Hisar, anju_gju@yahoo.com

2. Assistant Professors, Haryana School of Business, Guru Jambheshwar University of Science \& Technology, Hisar, u_savita@yahoo.co.in

Corresponding Author

Dr. Anju Verma, Assistant Professors, Haryana School of Business, Guru Jambheshwar University of Science \& Technology, Hisar, anju_gju@yahoo.com 
With positive significant changes in terms of FDI coming up in multi and single brand retail, the opportunities are bound to come. In terms of employment, retail in India is the second largest employer. After agriculture, majority of the people are engaged in retail or related activities providing jobs to 9.4 per cent of all work forces available in India (Amin 2008). But majority of the people are engaged in unorganized sector. With increasing share of organized sector and huge investments flowing in, the job opportunities are on the rise. The job openings are mounting but unfortunately the labour productivity in Indian retail sector is low. It is merely 6 per cent of the labour productivity levels in US (Amin 2008). Hence more competent and skilled persons are required in the sector so that the labour productivity levels could be higher. In order to grab the job opportunities coming up in this sector, the labour force need to be more skillful and acquaint themselves with the job profile so as to become proactive in this regard.

\section{Review of literature}

Retail as a career option has been treated for research by many researchers. Swinyard (1981) and Swinyard et al. (1991) initiated by reporting the fact that college students did not have favourable perception towards career in retail. But few years later researchers like Commins and Preston (1997), Hart et al. (1999) found that the negative perception that people held has changed and retail is being considered as an attractive career destination by United Kingdom (UK) graduates because of increased number of retail degrees provided by UK universities and promotional activities by Consortium of British Retail Training Organisations (CORTCO). However Commins and Preston (1997) also reported that the retailers (job providers) still felt that retail is treated as relatively unattractive career by the students. Study by Broadbridge et al. (2007) reports that almost half of the students who worked in retail have positive experiences at work. Around a quarter of students with retail experience would take up a retail job and other quarter could be persuaded to work in retail.

\section{Job skills for retail stores}

Attracting right kind of talent into the retail sector is a challenge for the retailers. Many researchers have attempted to identify the skills required to perform retail job. Gush (1996) reported that self- skills and communication skills were most important qualities sought by employers. He also reported that British Retail Consortium (BRC) defined self confidence and personal strength; leadership and teamwork; planning and organization, analytical and problem solving; human relations and influencing skills are key to success in retail jobs. Overall academic performance and degree classification were least important factors considered by the employers. Quality in Higher Education (QHE) research found that retailers focused on in-house training for knowledge and skills rather than a degree as informed by Gush (1996). Saunders et al. (2004), in support to the findings of Gush (1996), found that skills related to communication, numeracy, information technology, problem solving and team work, were critical for retail job. McGauran (2004) said that Parisian managers considered personal qualities and social skills important along with professional sales skills whereas Dublin managers emphasized personal qualities rather than professional skills.

Kumar and Jain (2010) found that communication skill, working with group, adaptability, responsibility, interaction skill, proactive and initiation skill, customer orientation, appearance, task perseverance, operational skill, creativity and problem solving, work performance and technology skills are the survival skills for a retail job in Middle East. Nickson et al.(2012) reiterated that soft skills need to be emphasized at the entry level retail jobs. Moreover, it is emphasized that there is need for broadening soft skills including aesthetic labour. 


\section{Job profile in retail stores}

Job profile is a region which is not been researched extensively by the researchers. Gush (1996) reported that graduates expect good training and structured development within a reputed company; career prospects; interesting and challenging job from a retail job. Commins and Preston (1997) and Broadbridge (2001) found that students have limited information about the duties of retail job. And this awareness of a retail career among students was restricted to information provided by retailers in form of brochures and meetings/presentations at career fair (Commins and Preston, 1997). Students' perceptions of retailing as a future career were also based on their experiences as consumers or part-time employees (Broadbridge 2003). Broadbridge (2003) attributed that retail career were people/customer oriented, challenging and interesting but had poor salary. She also found that graduates working in store based positions sought greater autonomy and decision making within retailing. Knight and Crutsinger (2003) had reported that college graduates currently employed or planning to pursue retail career expected enjoyable work, sense of accomplishment, good pay and opportunities to develop new skills. Similar results were found by Broadbridge et al. (2007) who highlighted that students look for enjoyment from work, fairness, equality and tolerance. Determined to succeed, personal goals and good pay were most important factors for a retail job however, moving companies and working long hours were least important. Hart et al. (2007) found that there is mismatch between the supply and demand of requirements in retail jobs. They identified that the employers consider attitude gap and management skills gap in retail entrants in UK.

The job experiences studied by various authors were general in nature. More specifically, Commins and Preston (1997) reported that job profile include maximizing sales, providing customer service, managing systems, controlling costs and enforcing safety standards. As informed by undergraduates other frequently highlighted duties included staff management, selling, displays and customer services. Johlke and Iyer (2013) indicated that the characteristics of the retail employee's work environment are associated with enhanced job attitudes and reduced ambiguity. However they found that greater amounts of job autonomy are associated with increased levels of ambiguity.

\section{Significance of the Study}

The lucrative Indian retail sector has resulted in huge amount of job opportunities coming up. The retail employers are also eyeing on the talent inflow in this sector. Awareness about the skills required and the duties to be performed on the job will not only help the prospective but the present employees to understand and perform their duties in pleasing and satisfying manner and contribute to increased labour productivity level. Not only this, the understanding of the kind of skills required to perform the store operations and the duties to be carried out in front end store operations will provide an idea to the educators to guide and help develop these skills in the students who will be the prospective employees. So taking into consideration these facts it becomes vital to identify the job skills and job profile for store operations as the number of stores coming up in this part of world.

\section{Objectives of the Study}

The present study can be viewed as an attempt to provide an in-depth perceptive of the students (prospective employees) and existing employees of retail sector about the gap between students' perception about the level of skills required and the actual level of skill required as mentioned by retail employees, so that students can develop the skills and make themselves ready for the race. Having an idea of the duties to be performed they can fulfill the tasks well and contribute to the company's success and their own career development once they are in the job. Keeping this in mind, the research is undertaken to throw light on the two considerations 
of retail store jobs comprising of job skills and job profile. More specifically the objectives are to -

(a) to summarize the job skills required for retail store operations;

(b) to outline the job profile for retail store operations; and

(c) to identify the gaps in the perspective of students (prospective employees) and present employees for job skills and job profile.

\section{Methodology}

In order to achieve the stated objectives, a structured questionnaire comprising of the statements related to job skills and job profile of retail store operations was developed. The statements were drawn from previous researches which included the works of Gush (1996); Broadbridge et. al (2007); and Hurst and Good (2009). The other statements were drawn from the authors' research including the skills required and job profiles for retail store jobs advertised on various Indian job websites. The purpose of this act was to include the different skills required and duties to be performed in a retail store job in Indian setting. This was done to capture the actual job skills and job profile as demanded by the Indian retailers. Likert type 5 point scale was used to gather the responses. For carrying out the pilot survey, 28 and 35 statements related to job skills and job profile respectively were included. The questionnaire was finally sent to people who teach / practice retail store operations to check the validity. The final version of the questionnaire included 13 statements of job skills and 14 statements of job profile.

The sample constituted retail stakeholders i.e. students (prospective employee) and present employees. Students included in the study were the final year students with marketing specialization and pursuing their degrees in various Universities and Management Institutions in the state of Haryana. In total 200 students were included in the study. Retail employees with at least one year experience in same sector were also included. 108 existing employees involved in store operations were examined. Every sincere effort had been made by the researchers to avoid biasness in the selection of respondents.

\section{Data Analysis, Interpretation and Result Discussion}

The respondents were asked to give response regarding the skills required for the retail jobs and the duties to be performed in stores. The collected responses were coded and tabulated and then data reduction technique (Factor Analysis) was applied to extract the latent factors. In order to test the significance level of the gaps between the opinions of both sets of respondents (students and retail employees) student t-test was applied thereafter for skills and job profile.

\section{Job skills}

Factor Analysis was carried out to measure linear combination of some latent factors of job skills. Principal Component Analysis with Kaiser Normalization has been used as a method for obtaining the initial factors. Kaiser-Meyer-Olkin Measure of Sampling Adequacy test was applied initially; the value came out to be 0.665 thereby hinting that the data is adequate. The value for Bartlett's Test of Sphericity came out to be 545.166 at 0.000 significant level, which means that the correlation matrix is not identical hence fit for factor analysis.

A total of six components were extracted from rotation matrix out of fourteen original variables. Eigen values were 1.712, 1.705, 1.553, 1.371, 1.326 and 1.264. These six extracted factors together account for 63.791 per cent of cumulative variance. Thus the six extracted factors are able to retain approximately 64 per cent information. The nomenclatures of factors were done on the bases of nature of the variables constituting factors. 
The six factors extracted are named as technical skills (factor 1), liasioning skills (factor 2), creativity skills (factor 3), interactive skills (factor 4), leadership skills (factor 5) and prior degree / course (factor 6). Job skills explain the various skills required to perform the jobs at retail stores. The aspirants (MBA students) and existing store employees were asked about these skills and their differences in opinions were calculated afterwards.

Table 1 reveals the statistical matrix constituting factor analysis and t-test. Technical skills (factor 1) are found most contributing factor as it explains 12.227 per cent variance to cumulative variance. This factor is explained by four original variables namely: require prior work experience, good writing skills, computer handling skills and analytical skills with factor loadings of $0.801,0.612,0.604$ and 0.530 and each variable shares the variance as: $0.715,0.579$, 0.664 and 0.523 respectively. From the said table, it is also seen that both the samples (students as well as employees) have opposite opinion as employees perceive that technical skills are importantly required to perform retail job while students do not think that way (based on the mean values which is 3.610 and 3.912 for students and employees respectively). This difference is significant too as the significance level of $t$-value (-5.074) is less than 0.05 .

\section{Table 1: Factors Determination and Comparing the Perception of Students Opted for Retail as Career Option and Expectations of Retail Employees for Job skills}

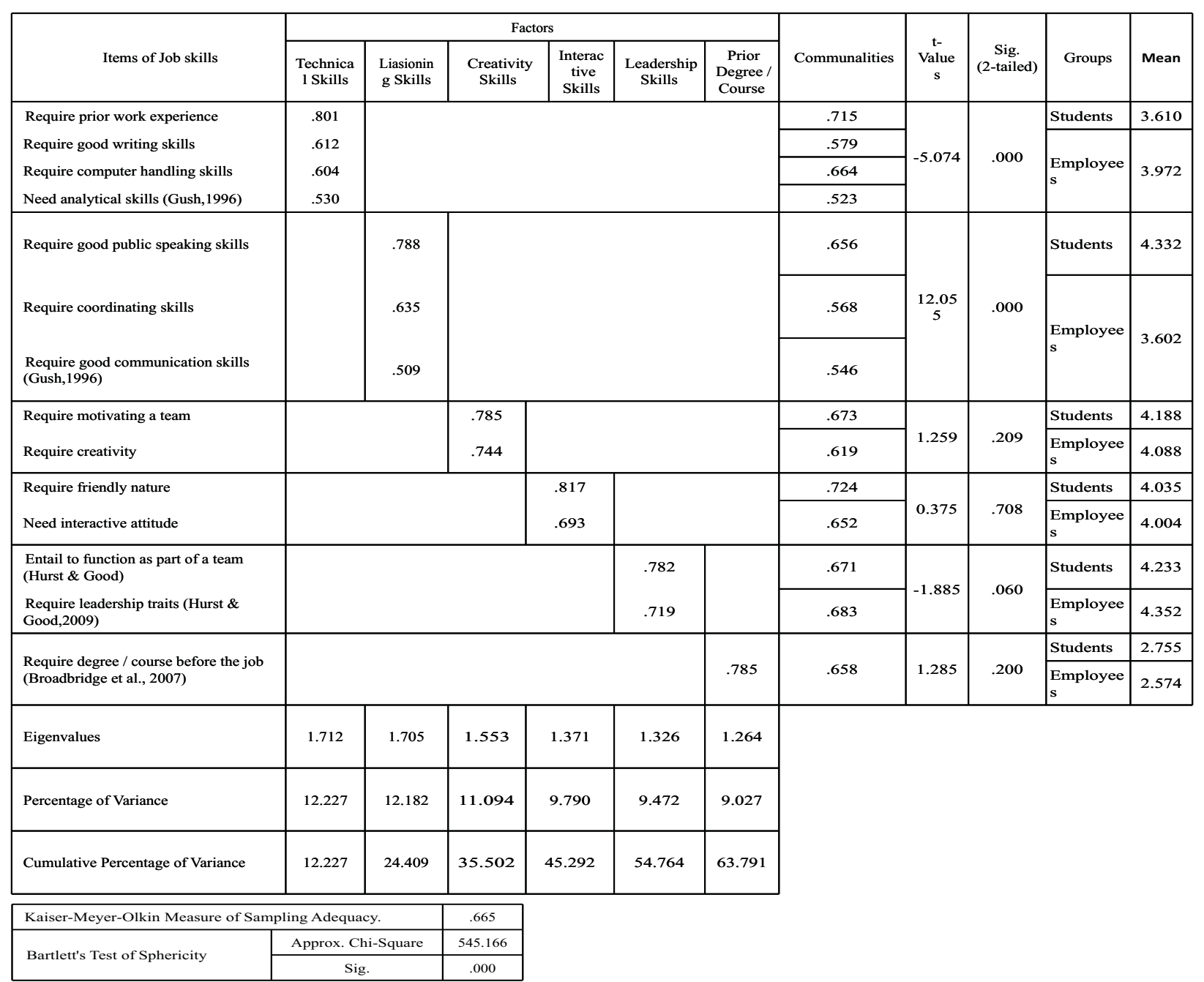

Source: Field Survey

Note: The items drawn from the literature, is mentioned in the parenthesis along with the items.

Rests of the items are drawn from authors' research. 
Prior work experience obviously makes a person more confident while performing a job than a fresh / non-experienced person and good writing skill always makes a person more logical and presentable. Today computer is an integral part of everything and retail is no exception. In retail too, it plays an important role. Analytical skills enable the persons to take right decisions and to tackle the unforeseen situations. Therefore, technical skills no doubt are important and students should focus on these skills.

Second factor is liasioning skills constituting three variables namely: require good public speaking skills, coordinating skills and good communication skills with factor loading 0.788, 0.635 and 0.509 respectively. It explains 12.182 per cent variance to cumulative. Retail job by nature is a liasioning job as the employees are continuously in contact with the customers. Therefore, this factor plays an important role. Each variable of this factor shares $0.656,0.568$ and 0.546 variance. Here too the employees and students have opposite opinions as students think that liasioning skills are more important while employees think that this skill is less important (the mean value for students is 4.332 and for employees it is 3.602). This difference is also found significant, as the significant level of $t$-value (12.055) is less than 0.05 . Retail employees need to take care of laisioning skills. As they are not found very good in this skill while interacting with customers they are of the opinion that the jobs in store operations can do with less of laisioning with others. However, today's competitive environment demands such kind of skills. The students who presently are the customers at retail stores feel that the employees should have more of laisioning skills so that they can take care of the customers in a better way.

Creativity skills comprising two original variables namely: require motivating a team and creativity with factor loading 0.785 and 0.744 with communalities 0.673 and 0.619 constitute the third factor. It explains 11.094 per cent variance to cumulative. The $t$-value is 1.259 at level of significance .209 as the significance value is greater than 0.05 the mean difference between the employees and students are not found significant though they seems opposite (mean value for students is 4.188 and for employees is 4.088) in opinions regarding the importance of creativity skills. Retail job includes team spirits. To maintain team spirit, motivational strategies and creativity is required. Hence, both ends should focus on developing this factor.

Interactive skill is found to be fourth factor pivotal for retail jobs in stores, comprising of two original variables namely: friendly nature and interactive attitude with factor loading 0.817 and 0.693 with communalities 0.724 and 0.652 respectively. It explains 9.790 per cent variance to cumulative. The $t-$ value is 0.375 at level of significance 0.708 . As the significance value is greater than 0.05 the mean difference between the employees and students is found insignificant for opinions regarding the importance of interactive skills. Both the groups i.e. students and employees feel that interactive skills are necessary. To survive in intense competition customer relations is an effective tool which can be maintained by friendly nature and with interactive attitude. Hence, again both ends should work on it.

The next factor that comes out is leadership skills comprising two original variables namely: function as part of team and leadership traits with factor loading 0.782 and 0.719 with communalities 0.671 and 0.683 respectively. It explains 9.472 per cent variance to cumulative. The $\mathrm{t}$-value is -1.885 at level of significance 0.060 so the mean difference between the employees and students are not found significant regarding the importance of leadership skills in retail store jobs. Both the samples feel that in retail jobs leadership skills has its own significance.

Last factor in relation to job skills is prior training comprising single original variables namely: prior training before job with factor loading 0.785 with communality 0.658. It explains 9.027 per cent variance to cumulative. The $\mathrm{t}$-value is 1.285 at 0.200 levels of significance, as the significance value is 
greater than 0.05 the mean difference between the employees and students are not found significant. Both the segments under preview agree to the importance of prior degree/course before taking up the job. Prior degree/course provides aspiring retail employees to have the information about what is to be done in retail job and help them polish the skills during the course so that the jobs in retail stores could be performed in a better way. The learning during the job also speeds up if some related course has been done.

\section{Job profile}

Table 2 explains the statistical measures for job profile, which explains the elements of retail jobs. The value for Kaiser-Meyer-Olkin Measure of Sampling Adequacy test is 0.697, which means data is adequate. The value for Bartlett's Test of Sphericity is 710.836 at 0.000 significant levels. In total five components are extracted out of fourteen original variables from rotation matrix. Eigen values are $1.874,1.840,1.728,1.546$ and 1.472. These five extracted factors together account for 60.429 per cent of cumulative variance. The nomenclatures of factors are done on the bases of nature of the variables constituting factors. The five factors extracted are named as flexible working arrangements (factor 1), responsiveness (factor 2), sales analysis (factor 3), contributing towards society and company (factor 4), and other issues (factor 5).

A flexible working arrangements (factor 1) is most contributing factor as it explains 13.388 per cent variance to cumulative variance. This factor is explained by three original variables namely: work includes many nights/weekends, retail job is concerned with working extra hours and offers sufficient levels of responsibility and power, with factor loading of $0.821,-0.754$ and 0.642 and each variable shares the variance (communalities) as: $0.708,0.593$ and 0.509 respectively.

Table 2: Factors Determination and Comparing the Perception of Students Opted for Retail as Career Option and Expectations of Retail Employees for Job Profile

\begin{tabular}{|c|c|c|c|c|c|c|c|c|c|c|}
\hline \multirow[b]{2}{*}{ Items of Job profile } & \multicolumn{5}{|c|}{ Factors } & \multirow[b]{2}{*}{ Communalities } & \multirow[b]{2}{*}{$\mathrm{t}$-Values } & \multirow[b]{2}{*}{$\begin{array}{c}\text { Sig. } \\
\text { (2-tailed) }\end{array}$} & \multirow[b]{2}{*}{ Groups } & \multirow[b]{2}{*}{ Mean } \\
\hline & $\begin{array}{c}\text { Flexible } \\
\text { Working } \\
\text { Arrangeme } \\
\text { nts }\end{array}$ & Responsiveness & $\begin{array}{l}\text { Sales } \\
\text { Analysis }\end{array}$ & $\begin{array}{c}\text { Contributing } \\
\text { towards } \\
\text { Society and } \\
\text { Company }\end{array}$ & $\begin{array}{l}\text { Other } \\
\text { Issues }\end{array}$ & & & & & \\
\hline $\begin{array}{l}\text { Work includes many } \\
\text { nights/weekends* }\end{array}$ & \multirow{3}{*}{$\begin{array}{l}.821 \\
-.754\end{array}$} & & & & & 0.708 & \multirow{3}{*}{4.729} & \multirow{3}{*}{.000} & Students & 3.403 \\
\hline $\begin{array}{l}\text { Is concerned with working } \\
\text { extra hours* }\end{array}$ & & & & & & 0.593 & & & \multirow{2}{*}{ Employees } & \multirow{2}{*}{3.090} \\
\hline $\begin{array}{l}\text { Offer sufficient level of } \\
\text { responsibility and power* }\end{array}$ & & & & & & 0.509 & & & & \\
\hline $\begin{array}{l}\text { Identifying and responding to } \\
\text { customers' complaints }\end{array}$ & & .788 & & & & 0.649 & \multirow{4}{*}{-1.413} & \multirow{4}{*}{.159} & Students & 4.176 \\
\hline $\begin{array}{l}\text { Keeping a watch on what local } \\
\text { competitors are doing }\end{array}$ & & .664 & & & & 0.483 & & & & \multirow{3}{*}{4.266} \\
\hline $\begin{array}{l}\text { Ensuring service delivery to the } \\
\text { customers }\end{array}$ & & .584 & & & & 0.561 & & & Employees & \\
\hline $\begin{array}{l}\text { Responding to customers' } \\
\text { comments }\end{array}$ & & .507 & & & & 0.532 & & & & \\
\hline
\end{tabular}




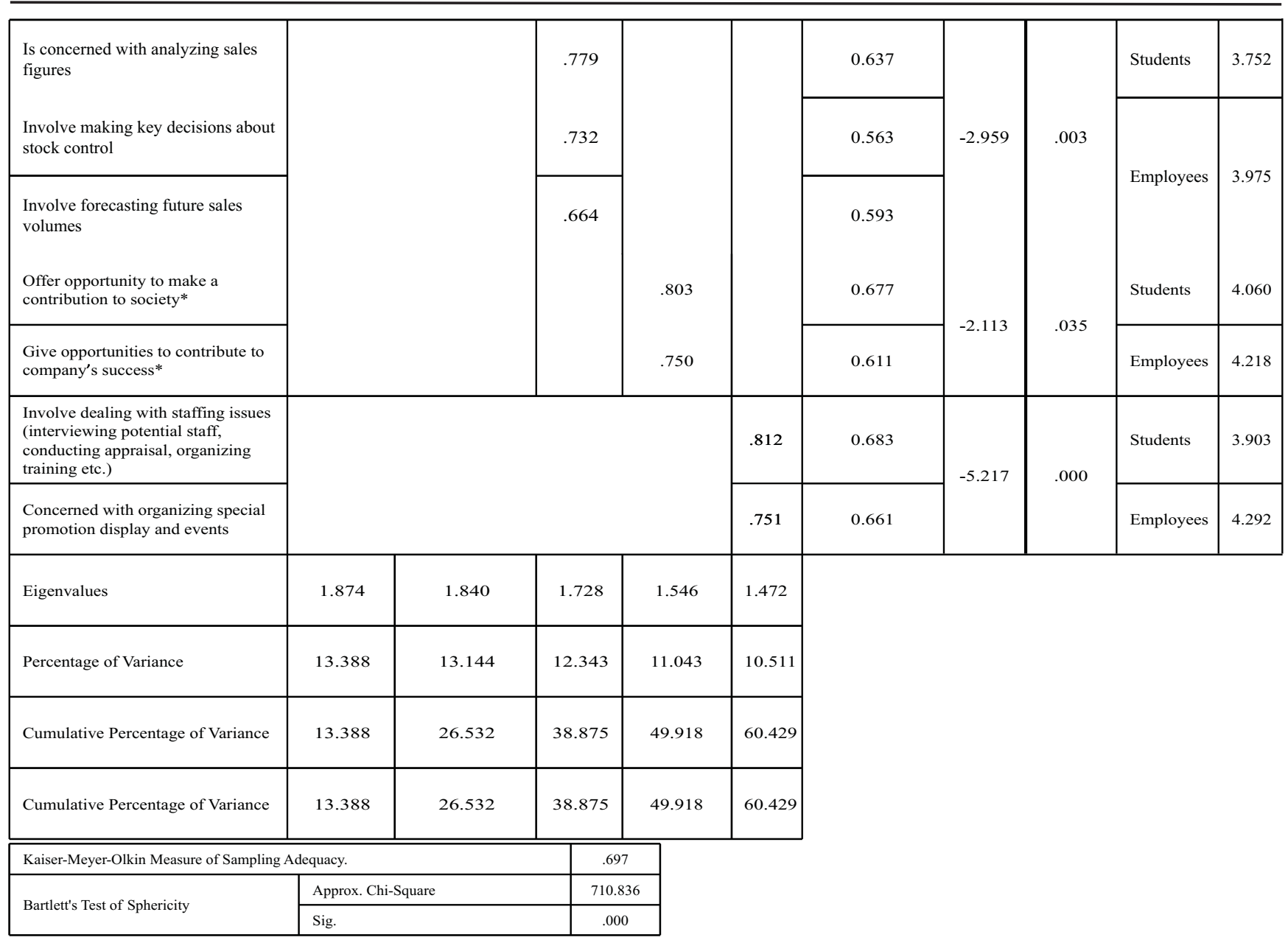

Source: Field Survey

*= Items are drawn from Hurst \& Good, 2009 and rest of the items are drawn from authors' research

It is seen that the opinion regarding the flexible working arrangements, both the samples (students as well as employees) have opposite opinions. This difference is found significant with t-value (4.729) and significance level less than 0.05 .

The mean value for students is 3.403 and for employees mean value is 3.090. It means students agree that retail jobs include flexible working arrangements including nights and weekends, while the employees think differently. Retail jobs by nature include timings, which are suitable to the customers. The students feel that a retail store job may have unsuitable work timings however, the employees feel that the timings are flexible enough to be managed. It also offers sufficient levels of power and responsibility to the retail employees. Hence, the students need not worry regarding the odd timings.

Second factor is responsiveness constituting four variables namely: identifying and responding to customers' complaints, keeping a watch on what local competitors are doing, ensuring service delivery to customers and finally, responding to customers' comments with factor loadings of 0.788 , 0.64. 0.584 and 0.507 respectively. It explains 13.144 per cent variance to cumulative. Retail job by nature is a job where the employees are directly in contact with customers. If the customer faces any problem or provides any comment, it becomes imperative for the employees to respond to it and satisfy the customers. Responding to customers would help enhance the image and relationship. In marketing one has to keep an eye on what the competitors are 
doing and in retail it becomes even more important. The retailers have to frame their strategies in accordance to the competition. The retail employees are involved in the responsiveness towards the customers and local competition. Each variable of this factor shares $0.649,0.483,0.561$ and 0.532 variance. This difference for students and employees is found non-significant, as the significant level of tvalue $(-1.413)$ is greater than 0.05 . Retail employees and the students understand the importance of responsiveness similarly.

Sales analysis is third factor comprising of three original variables namely: concerned with analyzing sales figures, making key decisions about stock control and forecasting future sales volume with factor loading $0.779,0.732$ and 0.664 with communalities $0.637,0.563$ and 0.593 . It explains 12.343 per cent variance to cumulative. The $t$-value is -2.959 at level of significance 0.003 , which is less than 0.05 indicating that both the respondents (employees and students) have opposite opinions regarding the sales analysis. Every organization is directly concerned with sales figure and retail basically is a sales based operation. Hence, this is a crucial element. The retail employees more understand the importance of such element than the aspirants (students) as the mean value for employees (3.975) is greater than mean value for students (3.752).

Contributing towards society and company is found to be fourth factor comprising two original variables namely: offer opportunity to make a contribution to society and give opportunities to contribute to company's success with factor loading 0.803 and 0.750 with communalities 0.677 and 0.611 respectively. It explains 11.043 per cent variance to cumulative. The $t$-value is -2.113 at level of significance $0.035(\mathrm{p}<0.05)$. Thus the mean difference between the employees and students is found significant and they seem opposite (mean value for students is 4.060 and for employees is 4.218) in opinions regarding the contribution towards society and company. It is important for any job to give satisfaction. Apart from the other things, the satisfaction comes when the employee feels that the job he/she is doing is contributing to the society and company. The people who are involved in retail jobs i.e. retail employees has experienced that the retail jobs offer satisfaction to them. However, the students (prospective employees) feel differently. The students need to understand that the retail jobs will provide the satisfaction that they desire.

Last factor is other issues comprising two original variables namely: dealing with staffing issues and organizing special promotion displays and events with factor loadings of 0.812 and 0.751 with communalities 0.683 and 0.661 respectively. It explains 10.511 per cent variance to cumulative. The $\mathrm{t}$-value is -5.213 at level of significance 0.000 . As the significance value is less than 0.05 , the mean difference between the employees and students are found significant and they are opinioned opposite too (mean value for students is 3.903 and for employees is 4.292). Though these two variables are opposite in nature but comprising one factor. Both the variables are important and form integral part of retail jobs in stores. Students feel that retail jobs are less concerned with HR issues as well as promotional issues while the existing retail employees knows the importance of such issues. They opine that retail jobs are more concerned with HR issues and displaying products and events.

\section{Conclusion and Policy Implications}

The present study has identified the skills required and duties to be performed in retail store jobs. Various authors have defined the skills required for retail jobs. However, all the studies are based in other nations especially the Western countries. No study was found with Indian setting.

With large number of retail jobs coming up in India it is important to study the skills required in Indian organized retail. The study has identified technical skills, liasioning skills, creativity skills, interactive skills, leadership skills and prior training pivotal to retail job. The educators should help the students 
develop these skills so that the students do not face any difficulty during retail job. Developing the skills will also help the students crack the right kind of job in retail. They will be able to execute their jobs in improved way. So, the students need to grow these skills to become successful in retail sector. The students should take care of developing technical skills during their degree course as they feel that less technical skills are required for retail job.

Taking into consideration the Indian scenario, the demand is more than supply, the existing employees feel that liasioning skills are not much relevant in retail store jobs. The students, who have the experience of the retail customer, feel that liasioning skills are more important as retail is customer oriented sector. The retail employees need to inculcate these skills. Similarly, the students will have to develop these skills so that they can have upper hand in their future job. Leadership skills are required more as opined by the employees. Students should sharpen the leadership skills and entail to function as a part of team.

For the job profile, the study has identified flexible working arrangements, responsiveness, and sales analysis, contributing towards society and company, and other issues including $\mathrm{HR}$ issues and promotional displays and events as necessary part of a retail job. The students feel that retail job will provide them less opportunity to contribute towards society and company. But the employees have reported that retail provide them opportunity to contribute towards society and company. This could be a motivating factor for students as they can pay back to the society and company which might enhance their self-satisfaction. As far as other issues including HR issues and promotional displays and events are concerned, the employees feel that these are important part of retail job. However, the students feel the other way. The retail job will provide the employees to show their creativity in organizing promotional displays and events. The employees will have to indulge in HR activities also.
The retail store and aspiring employees will have to understand the significance of the skills required and the kind of duties to be performed in retail store job, so that the same can be done in effective and efficient manner. With so much of opportunities coming up in organized retail, it is up to the students how well they grab it.

\section{REFERENCES}

1) Amin, M. (2008), "Labor regulation and employment in India's retail store", Retrieved on May 21, 2012, www.siteresources.worldbank.org /SOCIALPROTECTION/Resources/SPDiscussi on-papers/labor-Market-DP/0816.pdf.

2) Broadbridge, A. (2001, 15 June), "Industry urged to improve image of retail as a career", Retail Week, 39.

3) Broadbrigde, A. (2003), "Student perception of retailing as a destination career", International Journal of Retail \& Distribution Management, 31(6), 298-309.

4) Broadbrigde, A., Maxwell, G.A. and Ogden, S.M. (2007), "Students' views of retail employmentkey findings from generation $\mathrm{Ys}^{\prime}$ ", International Journal of Retail \& Distribution Management, 35(12), 982-992.

5) Commins, J. and Preston, D. (1997), "The attractiveness of retailing as a career for graduates: An update", International Journal of Retail and Distribution Management, 25(4), 120-5.

6) FDI in multibrand to boost organized retail in India, (2012, August 13), The Economic Times, Retrived September 2012, http:/ / articles.economictimes.indiatimes.com/2 012-08-13/news/33182674_1_fdi-global-retailchains-gdp-growth.

7) Gush, J. (1996), "Graduates into the retail industry: An assessment of the nature and causes of mismatches between the needs and expectations of the retail industry and its graduate employees", International Journal of Retail \& Distribution Management, 2(9), 5-12.

8) Hart Cathy, Grazyna B. Stachow, Andrew M. Farrell \& Gary Reed, (2007),"Employer 
perceptions of skills gaps in retail: Issues and implications for UK retailers", International Journal of Retail \& Distribution Management, 35 (4), $271-288$.

9) Hurst, J.L. and Good, L.K. (2009), “Generation Y and career choice the impact of retail career perceptions, expectations and entitlement perceptions", Career Development International, 14(6), 570-593.

10) Johlke, M. C., \& Iyer, R. (2013), “A model of retail job characteristics, employee role ambiguity, external customer mind-set, and sales performance", Journal of Retailing and Consumer Services, 20(1), 58-67.

11) Knight, D. and Crutsinger, K. (2003), Retain work expectations and experiences: implications for retaining college students in the university, University of North Texas at Denton. Denton, TX, unpublished manuscript.

12) Kumar Dileep M. and Jain, V. (2010), “Survival skills of business management graduates: A study with reference to retail and banking", Far East Journal of Psychology and Business, 1(1), 59-77.

13) McGauran, A.M. (2004), "Comparing student employment in French and Irish retailing", International Journal of Retail \& Distribution Management, 32(5), 259-269.

14) Nickson, D., Warhurst, C., Commander, J., Hurrell, S. A., \& Cullen, A. M. (2012), "Soft skills and employability: Evidence from UK retail", Economic and Industrial Democracy, 33(1), 65-84.

15) Paulins, V.A. (2008), "Characteristics of retailing internships contributing to students' reported satisfaction with career development", Journal of Fashion Marketing and Management, 12(1), 105118.

16) Saunders M.N.K., Skinner D. and Beresford R. (2005), "Mismatched perceptions and expectations: an exploration of stakeholders' views of key and technical skills in vocational education and training", Journal of European Industrial Training, 29(5), 369-382.

17) Swinyard, W.R. (1981), "The appeal of retailing as a career", Journal of Retailing, 57(4), 86-97.
18) Swinyard, W.R., Langrehr, F.W. and Smith, S. M. (1991), "The appeal of retailing as a career: a decade later", Journal of Retailing, 67(4), 451-65. 